\title{
Climate Change Communication in Colombia
}

Luisa F. Lema Vélez, Daniel Hermelin, Margarita Fontecha and Dunia H. Urrego

\section{Summary}

Colombia is in a privileged position to take advantage of international climate agreements to finance sustainable development initiatives. The country is a signatory of the United Nations Framework Convention on Climate Change (UNFCCC), the Kyoto Protocol, and the Paris Agreements. As a non-Annex I party to the UNFCCC, Colombia produces low emissions in relation to global numbers $(0.46 \%$ of total global emissions for 2010$)$, and exhibits biogeographical conditions that are ideal for climate change mitigation through greenhouse gas sequestration and emission reductions. Simultaneously, recent extreme climatic events have harshly compromised the country's economy, making Colombia's vulnerability to climate change evident.

While these conditions should justify a strong approach to climate change communication that motivates decision-making and leads to mitigation and adaptation, the majority of sectors still fall short of effectively communicating their climate change messages. Official information about climate change is often too technical and rarely includes a call for action. However, a few exceptions exist, including environmental education materials for children and a noteworthy recent strategy to deliver the Third Communication to the UNFCCC in a form that is more palatable to the general public. Despite strong research on climate change, particularly related to agricultural, environmental, and earth sciences, academic products are rarely communicated in a way that is easily understood by decision 
makers and has a clear impact on public policy. Messages from the mass media frequently confuse rather than inform the public. For instance, television news refers to weather-related disasters, climate variability and climate change indistinctively. This shapes an erroneous idea of climate change amongst the public and weakens the effectiveness of communications on the issue.

The authors contrast the practices of these sectors with those of non-governmental organizations (NGOs) working in Colombia to show how they address the specific climate communication needs facing the country. These NGOs directly face the challenge of working with diverse population groups in this multi-cultural, multi-ethnic and megadiverse country. NGOs customize languages, channels and messages for different audiences and contexts with the ultimate goal of building capacity in local communities, influencing policy makers and sensitizing the private sector. Strategies that result from the work of interdisciplinary groups, involve feedback from the audiences and incorporate adaptive management have proven to be particularly effective.

\section{Keywords}

Colombia, climate change, communication for decision-making, communication strategies, media, government, academia, NGOs, natural disasters, community empowerment, capacity building, adaptability.

\section{Introduction}

Colombia is a signatory of international climate change agreements and is well positioned to take advantage of these agreements to finance sustainable development. First, 
Colombia is not considered a large greenhouse gas (GHG) emitter, and, second, its biogeographical characteristics are particularly advantageous for mitigating climate change through GHG sequestration and emission reduction. The country also contains large forested areas that add up to $52 \%$ of its total surface area (53 million hectares). The majority of the forested areas are part of the Amazon and Chocó-Darien biomes and possess a large capacity to store above and belowground carbon. Approximately $75 \%$ of existing forest remnants lie within collective territories of Indigenous and Black communities ${ }^{i}$. Consequently, the national government is required to negotiate the design and inception of carbon mitigation projects with local communities. Implementing communication strategies that engage these different cultures is key to the success of national GHG sequestration and emission reduction mitigation initiatives in the country.

To analyse how different stakeholders address climate change communication within a complex context, this paper examines the challenges and approaches of climate change communication in Colombia through the perspective of four different stakeholders: the government, the academic sector, the media, and non-profit organizations. These are the primary sources of information on climate change for the general public and decision-makers. This paper shows how these four stakeholders are inter-connected. It uses case studies to illustrate climate change communication evolution within each of these sectors. To the best knowledge of the authors, this is the first comprehensive review of climate change communication in Colombia. 


\section{The case of Colombia}

\section{Colombia's ethnic, cultural and biological diversity}

Colombia's natural values are well recognized. The country is ranked second in the National Biodiversity Index (Secretariat of the Convention on Biological Diversity, 2001), houses at least two biodiversity hotspots (Myers et al., 2000), and hosts over 10\% of currently known species worldwide (Instituto de Investigación de Recursos Biológicos Alexander von Humboldt, 2012). The country is divided into five terrestrial ecoregions: Chocó, Caribbean, Amazon, Orinoco savannah, and Andes. Additionally, two coastal/marine regions are recognised: the Pacific Ocean and the Caribbean Sea (Ministerio de Ambiente y Desarrollo Sostenible, Programa de las Naciones Unidas para el Desarrollo, 2014). Both the Chocó and the Amazon ecoregions are acknowledged amongst the world's most biodiverse (Gentry, 1992; Murcia et al., 2013; Myers et al., 2000). Additionally, because the territory is located in the equatorial region and largely influenced by the Intertropical Convergence Zone, warm temperatures and high rainfall provide the ideal conditions for ecosystems to experience a high productivity, particularly those that are within lowland and premontane regions.

The country's biodiversity matches its cultural and ethnic diversity. Colombia has a colonization history that resulted in a rich mix of races, languages and traditions of American, European and African origins (Departamento Administrativo Nacional de Estadística [DANE], 2007). While the majority of the population is an array of Hispanic mixes, the country recognizes three ethnic groups: Indigenous (including 87 nations), Black or AfroDescendants (including Raizals, Palenque people, mulatto, and Black), and Romani (DANE, 2007). The 2005 nationwide census indicated that $13.77 \%$ of the population identified as a member of an ethnic group. The largest ethnic group is the Black community and AfroDescendants, with 4,311,757 people in the census ( $10.62 \%$ of the total population), followed 
by the Indigenous population (3.43\%; DANE, 2007). The majority of the Indigenous and Black community members live in rural areas in the plains, mountains, and coasts of the Chocó, Amazon, and Andean ecoregions (West, 1957).

Ethnic groups have specific rights in Colombia ${ }^{\text {ii }}$. Special constituencies exist for Indigenous and Black communities, each with two elected senators. Importantly, the country has constitutionally granted these groups a level of sovereignty that involves collective ownership of their territories and a large autonomy in land planning and management (Colombian Constitution, Law 70 of 1993). In the case of Indigenous communities, their territories are considered independent territorial entities -similar to municipalities- where they may exercise jurisdictional functions in accordance with their own rules and procedures, provided they are not contrary to the Constitution and laws of the Republic (Art. 246 of Colombian Constitution). The different ethnic groups represent 65 indigenous languages, 2 Creole, 1 Romani, and the most frequently used language, Spanish (Landaburu, 2004). These numbers provide an indication of the additional ethnic diversity found within the Indigenous and Black populations.

\section{Challenges and opportunities in climate change mitigation communication}

Colombia is a non-Annex I signatory of the United Nations Framework Convention on Climate Change (UNFCCC), the Kyoto Protocol, and the Paris Agreements. The country is positioned to take advantage of international climate agreements to finance sustainable development initiatives through carbon markets for two primary reasons. First, Colombia is not considered a large GHG emitter. The country generates approximately 174.4 Mton of $\mathrm{CO}_{2}$ eq, which is $0.46 \%$ of the total global emissions quantified for 2010 (Government of Colombia, 2015). Second, the biogeographical characteristics of vast and highly-productive forests described in further detail in the section Colombia's ethnic, cultural and biological 
diversity, are particularly advantageous to mitigate climate change through both GHG sequestration and emission reduction (Dixon et al., 1994).

In the $21^{\text {st }}$ session of the Conference of the Parties to the UNFCCC (COP21), December 2015, the country assumed an "Intended Nationally Determined Contribution" (INDC) to reduce $20 \%$ of GHG by 2020 (Government of Colombia, 2015). This target is extremely ambitious, considering that the country's manufacturing and agro-industries are still going through a growth phase. To achieve this goal, the government needs to halt deforestation and agriculture expansion, which are responsible for the majority of the country's emissions (Instituto de Hidrología, Meteorología y Estudios Ambientales [IDEAM] et al., 2015).

Colombia possesses one of the largest forested areas in the world, as $52 \%$ of the country's surface area still has forest cover, equalling approximately 53 million hectares (Departamento Nacional de Planeación, 2015). The majority of the forested areas lie within the Amazon and Chocó-Darien biomes. These biomes are characterised by tropical humid and hyper-humid forests with a large capacity to store above and belowground carbon (Asner et al., 2012). The country also contains large areas of the páramo ecosystem ${ }^{\mathrm{iii}}$ and extensive mangrove habitats that are important long-term carbon sinks (Alongi, 2012) and key for ecosystem-based adaptation measures (IDEAM, 2001). Despite the relatively good conditions of forests in the country, Agriculture, Forestry and Other Land Use (AFOLU) accounts for 76.3 Mton of $\mathrm{CO}_{2} \mathrm{eq}$, or $42.8 \%$, of the country's GHG emissions (IDEAM et al., 2015).

These good forest conditions present a significant opportunity for Colombia to participate in AFOLU carbon markets, both regulated and voluntary. Approximately $75 \%$ of the forest remnants lie within collective territories of Indigenous and Black communities 
(Ruiz García, 2006). As explained in Colombia's ethnic, cultural and biological diversity, Colombia has constitutionally granted these ethic groups a level of autonomy that involves collective ownership of the territories. For this reason, the national government is required to negotiate the design and inception of forestry mitigation projects, their strategies and their implementation with the communities. In addition, a significant portion of the country's income from the carbon credits may directly benefit these groups. Therefore, implementing communication strategies that engage these different cultures is key to the success of national AFOLU initiatives in the country.

The primary cause of deforestation is land clearing to establish pastures (Departamento Nacional de Planeación, 2015). Pasture establishment is only occasionally surpassed by illegal crop planting (i.e., predominantly coca). The dominant triggers for deforestation and degradation can differ amongst regions. In the Colombian Amazon, deforestation is primarily triggered by agricultural expansion, illegal crop cultivation, internal migration, mining, and infrastructure development (Nepstad et al., 2013). Selective logging is rare in the Colombian Amazon, and even traditional communities clear forests to extract wood and open plots for agriculture. The majority of deforestation in the Colombian Amazon starts with a slow movement of small peasants, followed by appropriation by larger tenants to establish ranching areas. In contrast, the forests of the Chocó region are submitted to degradation that does not always end in deforestation but still represents large GHG emissions (BioREDD, 2015). The primary cause of both deforestation and degradation in Chocó is selective logging for the wood industry (García Romero, 2014), a traditional activity widely practiced by Black communities.

Market dynamics, consumer education and value chains are strong variables that influence deforestation and degradation. Therefore, working on alternative sources of 
income, better production practices and conservation incentives for ethnic communities and peasants is an element commonly found in cooperative and governmental projects that aim to mitigate climate change through an AFOLU approach, and communication strategies should incorporate elements that aid in those purposes.

\section{Challenges and opportunities in climate change adaptation communication}

Colombia's vulnerability to climate change has been studied through direct evidence of temperature and rainfall fluctuations, as well as through projected climate scenarios. Evidence of climate change impacts is available in the agricultural sector (Centro Internacional de Agricultura Tropical [CIAT], 2013), biodiversity (Duque et al., 2015), health (Bouma et al., 1997; de la Mata \& Valencia-Amaya, 2014; Poveda et al., 2000), and fisheries (Allison et al., 2009). Climate change consequences for the country include losses of agricultural and biological diversity, an increase in the range of tropical disease vectors, and a reduction of fisheries. In addition, the National Planning Department leads a long-term research agenda on climate change implications and, in 2014, delivered a thorough analysis of the economic impacts for the country (Departamento Nacional de Planeación \& Banco Interamericano de Desarrollo, 2014). The analysis predicted a negative impact on the country's economy, with average projected annual reductions of $0.49 \%$ in GDP, represented in losses in the production of livestock, agriculture, fisheries and transportation, with only the forestry sector benefiting from climate change.

The effects of climate change on the national economy include losses and damages caused by strong ENSO events. Losses in the energy generation system are well documented for warm ENSO events in 1982-1983, 1992-1993 and 2014-2016 (Unidad Nacional para la Gestión del Riesgo de Desastres, 2014). Additionally, losses in housing, water and sanitation, public infrastructure and productive sectors are reported for the cold ENSO event of 2010- 
2011 (Comisión Económica para América Latina y el Caribe, 2012). The latter study evidenced that this extreme event resulted in 1,374 people dead, 1,016 people missing, $2,350,207$ disaster victims with personal or property losses, and damages of USD 6,052 million (5.7\% of GDP), and losses of USD 1,118 million ( $0.4 \%$ of GDP).

The large economic and social impacts of extreme climate events should be the basis for a strong argument that urges the government to consider climate change as a major driver in decision-making. Although Colombia has observed significant growth in the policies designed to address adaptation and mitigation, the application of these policies is poor. The country has not yet established efficient strategies to mitigate or adapt to climate change.

\section{Overview of knowledge on climate change communication in Colombia}

Research on climate change communication in Colombia has experienced little progress. Few studies exist on the role of the government, academia, private sector, social organizations or communities that take communication as a priority consideration. Progress regarding research on the role of the media in climate change communication is also weak. Studies show that the government is the primary source used by media to communicate climate change issues, while experts are a distant second as a source of information.

Specific efforts from diverse disciplines contribute to the understanding of climate change communication. Works edited by Ulloa (2011) and Ulloa \& Prieto-Rozo (2013) gather cultural perspectives on climate and, more specifically, on climate change from various areas of Colombia; although communication is not an explicit driver in these analyses, it is a crosscutting issue. Approaches and tensions or conflicts between communities, academia, experts, authorities and policies are disclosed in the publications, and provide inputs for policies and projects in adaptation and mitigation. Similarly, the work 
of Correa (2013) offers ideas for potential adaptation and mitigation measures, and addresses the tensions between traditional knowledge systems of various stakeholders, by presenting an ethnographic examination of the relationship between culture and climate for the inhabitants of the islands of Providencia and Santa Catalina in the Colombian Caribbean. These types of approaches open potential future pathways in the field of Communication Studies that could enrich other areas of Social and Human Sciences.

Some governmental agencies have tangentially examined climate change communication. Ruiz-Peña (2013) conducted a study for the Colombian Geological Service (Servicio Geológico Colombiano) on public understanding and appropriation of science in the communication between communities and authorities, with cases related to climate change. Similar efforts were carried out by the National Unit for Disaster Risk Management (Unidad Nacional para la Gestión del Riesgo de Desastres) and by the Medellin city authorities (López, 2008). In addition, the environmental authority of the Department of Antioquia provided an overview on the different issues related to climate change, developed in the context of the Paris 2007 UN IPCC meeting (Corantioquia, 2008). This work includes a chapter about climate change communication in Colombia that reviews the country's experience up to that date and explains some of its challenges, with special emphasis on mass media.

Regarding media, little research has been conducted on the role of traditional and emergent media in climate change communication in Colombia. Arcila et al. (2015a) presented an analysis of the content from 97 Spanish-language media websites from 19 countries (one being Colombia) that published news on climate change during the UNFCCC meetings in Cancun (COP16, 2010) and Durban (COP17, 2011). The work uses the framing theory to detect the relevance of the topics on the agenda and the treatment media give to 
them. Unfortunately, the paper does not specify which Colombian media were analysed, and, indeed, the findings are not disaggregated by country. The major finding is that politicians act as an important source of information for the media, while expert/scientist sources rank third. This fact also is discussed in the work of Zamith et al. (2012).

Arcila et al. (2015b) used an approach based on content analysis, with emphasis on framing. The authors examined how information was treated in 30 digital media in Spanish during the UNFCCC meetings in Nairobi (COP12, 2006), Bali (COP13, 2007), Poznan (COP14, 2008) and Copenhagen (COP15, 2009). The study includes the Colombian web portals of El Tiempo (the most widely read newspaper in the country), Semana (the most widely read magazine in the country), and El Universal (the most important regional newspaper in the city of Cartagena). The findings are general for all the media analysed and not particular to the Colombian case. Similar to Arcila et al. (2015a), this study shows that politicians are the main source of information for the media, although in this case politicians were followed more closely by experts/scientists. Another important finding is that the majority of the news included in the portals originates from news agencies. Both cases prove how media communication in Colombia does not respond, in general, to the country's needs.

Zamith et al. (2012) analysed media construction of climate change in national newspapers in the United States, Brazil, Argentina and Colombia in 2009. The study addresses framing ${ }^{i v}$ and analyses the Colombian newspaper analysed is El Tiempo. Notably, El Tiempo was the newspaper with the lowest number of climate change news articles of any newspaper amongst the sample. The results show that scientific controversy regarding climate change is much less important in Latin American newspapers than in the USA. In addition, the informational approaches of the newspapers from Argentina and Colombia employed more alarmist language than those from Brazil and USA, regardless the fact that 
Argentina and Colombia are lower emitters than the USA. The recurrence of sensationalist discourses in media is also noted in the study of Lima (2013) on Noticias RCN, the second most viewed television news program in the country. Similar to in Arcila et al. (2015a), and Arcila et al. (2015b), Zamith et al. (2012) showed that government is the most accessed source of information, and far exceed other sources, including academia.

Despite some progress, the dearth of research on the relationship between media and climate change communication in Colombia is evident. The first reason behind this reality may be the lack of importance that researchers in fields such as Communication Studies have placed on this issue. This could be partially explained by the weak development of research on science in the media, within the subfield of Public Communication of Science and Technology (PCST ${ }^{\text {vi }}$ ) (Arboleda et al. 2015, Pérez-Bustos \& Lozano-Borda 2011), which is a contrasting situation from what happens in other national contexts (see Schäfer \& Schlichting, 2014). Indeed, works such as those by Arcila et al. (2015a) and Arcila et al. (2015b), which include Colombian media in their sampling, do not originate from researchers in the PCST subfield. Additional analyses on media and disasters in the Andean region (including Colombia) are also not addressed by PCST (e.g., Miralles 2009, Obregon et al. 2009, Obregon et al. 2010). These works use approaches from Communication for Social Change or perform a critical analysis of journalism. They address climate change as it relates to disasters but not as a central issue.

Recognizing how climate change relates to other subjects, such as the economy or politics, reveals a particular relationship between environmental and scientific news in Colombian media. Although printed and online newspapers include independent sections to discuss environmental and science issues, these topics may overlap. This condition makes it difficult to distinguish whether or not the medium is communicating with a science outreach 
approach (Arboleda et al., 2011). In addition, some analyses can naturalize the separation between environment and science when analysing media and public perceptions and sometimes mix such subjects. Interestingly, public interest in environmental issues may be higher than in issues considered explicitly as scientific. When Daza (2009) registered answers of people from Bogota about their interest and/or knowledge related to science, the percentage of positive responses were low, but the knowledge stated by the interviewees increased significantly when science was associated to environmental issues, including climate change.

The second reason behind the lack of research on the role of the media in climate change communication in Colombia relates to the approaches and the schools of research adopted. Colombia has significantly advanced in what is referred to as Social Appropriation of Science and Technology (SAST) in the country. SAST is a research field (or subfield) of practices and research that has evolved with the support of Colciencias (the Administrative Department of Science, Technology and Innovation), which is closely related to the Public Understanding of Science field (Lozano-Borda \& Maldonado 2010, Pérez-Bustos \& LozanoBorda 2011, De Geiff \& Maldonado 2011, Falla et al., 2016). SAST has slight differences to PCST that are related to the more important role that Communication Studies plays in the latter (Hermelin, 2011, Pérez-Bustos et al., 2012). Both fields have been permeated by Social Studies of Science and Technology -by approaches similar to those presented in Hacket et al. (2008) - and barely influenced by Communication Studies. Media studies, particularly related to environment and climate change, have not been a priority for PCST or SAST studies in Colombia. Hermelin (2013) shows how combining the fields of Communication Studies and Social Studies of Science and Technology to study the relationship between disasters, media and society, enlarges the array of possible analyses. This combination of 
fields can be extended to analyse the relationship between climate change, media and society, and PCST can become particularly pertinent for this.

A third reason for the research vacuum in climate change communication is that climate change is an absent issue in the regular agenda (except when there is an active ENSO episode) and has not received much attention in Colombian media (particularly those with major audiences, such as television news). In the media agendas of the country, issues related to the armed conflict receive significantly more attention (Rey et al. 2005, Bonilla et al. 2004). Therefore, climate change is rarely featured in the news on the main broadcast television channels, and, in general, environmental programs are almost non-existent. No such programs have been featured in the schedules of the highest rated channels, Caracol and $R C N$, which are private, or Canal Uno, which is public. Environmental programs only appear in national public channels with the lowest ratings, such as Canal Institucional, or in local channels, such as Telemedellin (which belongs to the city of Medellin). Only a cable channel of Colombian origin, NTN24, has tried to maintain a climate program (Cli-Max), which covers topics related to climate change.

In Colombia, television is the most consumed medium and is where the majority of people report obtaining their scientific information (Daza-Caicedo \& Lozano-Borda, 2014). Colombian newspapers and news portals contain sections on the environment, and some radio station programs occasionally address climate change. This has resulted in an increase in the use of information and communication technology as a source of information on the environment and, in particular, climate change (Daza-Caicedo \& Lozano-Borda, 2014).

One positive effort to deal with the absence of climate change on the agendas of the country is the journalistic guide for the "green agenda" built by Organización Consejo de Redacción and Konrad Adenauer Foundation (Valencia, 2015). The goal of the guide was to 
promote perspectives to make climate change a relevant issue for journalists and their audiences, when addressing environmental issues. The guide uses a prescriptive discourse and promotes regional approaches to increase interest from the general public or from particular sectors of society. References to studies on media and climate change communication are scant in this work, not only when referring to Colombia but in general. The publication is a good example for the lack of interaction between journalism and research on the role of media in PCST (Massarani \& Ramalho, 2012), and particularly in relation to climate change. This interaction can be beneficial, as observed in Massarani et al. (2015) and in some of the work discussed by Schäfer \& Schlichting (2014), and remains a pending agenda in Colombia.

\section{Climate change communication as addressed by different sectors in Colombia}

\section{Climate change in governmental communication.}

Colombia is prolific in generating public policy documents, and climate change is not an exception At least four public policy documents relate directly to the subject ${ }^{\mathrm{ix}}$. Some of these documents briefly mention the importance of communication for the country's climate change mitigation and adaption (e.g., the National Plan for Climate Change Adaptation), and one of them specifically deals with education (the National Strategy for the Education, Training and Sensitization of Audiences on Climate Change). The implementation of different communication strategies, however, is not as active as policy drafting. One of these documents, the National Strategy for the Education, Training and Sensitization of Audiences on Climate Change (IDEAM, 2010b) includes a diagnosis of climate change communication from the government. This diagnosis may be the only overview that exists on the issue; however, it is not based on thorough data, but it is rather an informal and empirical exercise. 
Although there are indeed some direct efforts from the government to communicate through educational material (IDEAM, 2010b), the Colombian government has used three major channels for climate change communication: the media, documents and reports, and official websites. Media are reached through press releases, press conferences and direct declarations. The manner in which the government communicates has a large influence on how the media communicate. Zamith et al. (2013) found that government was by far the primary source of information on climate change news published in the most-read Colombian newspaper El Tiempo, as discussed in Climate Change in Colombian Media.

Documents and reports delivered by the government include information on mitigation and adaptation required by international agreements, policy documents and guidelines. These materials make information available on emissions, vulnerability, scenarios and measures for the country to address climate change. They target technical audiences in the government, NGOs and community organisations. The language is elaborate, demands at least a basic knowledge of the physics and ecology of climate change and is rarely translated into accessible language. Ironically, the low readability of this material hampers the possibility to influence decision-making at the highest level, as already noted by Barkemeyer et al. 2015 when analysing the readability of IPCC summaries.

Although sources that disclose Internet penetration differ greatly in the data they provide for Colombia, Internet use has certainly grown significantly in the country. For the period 2010-2015, statistics from the Ministry of Information and Communication Technologies ${ }^{\mathrm{x}}$ register an increase in penetration from $7.3 \%$ to $23.9 \%$, while statistics from Internet Live Stats ${ }^{\mathrm{xi}}$ exhibit an increase from $36.5 \%$ to $54.7 \%$ (Internet World Stats ${ }^{\mathrm{xii}}$ reports 26,000,000 Facebook users in June 2016, representing a 53.5\% penetration rate, which confirms that international stats may reflect reality better than local statistics). Internet sites 
are a major source of information for the Colombian public. Some national government agencies have specific sites or microsites to communicate about climate change. There are microsites dedicated to the topic housed within the website of the Ministry of Environment and Sustainable Development (Ministerio de Ambiente y Desarrollo Sostenible, MADS) and the Institute of Hydrology, Meteorology and Environmental Studies (Instituto de Hidrología, Meteorología y Estudios Ambientales, IDEAM). The National Planning Department uses a webpage $^{\text {xiii }}$ to publicize governmental documents related to adaptation and access to the Green Climate Fund. These documents are primarily policies, or guidelines to policies. The Ministry of International Relations also dedicates a webpage ${ }^{\text {xiv }}$ to present a thorough inventory of the main public policies developed by the country on the issue, as well as the international agreements subscribed. An effort to translate climatic information into data that the productive sector can use has been undertaken by the Ministry of Agriculture and Rural Development, who dedicates a webpage to a virtual bulletin on agro-climatic issues. The bulletin was first published in December 2014 and was written with the technical support of CIAT $^{\mathrm{xv}}$.

Both the MADS and IDEAM house microsites that include climate change related information. The ministry has three different sites $^{\mathrm{xvi}}$ : one with general information on what climate change is, press releases, a calendar of events and downloadable documents (policies and reports); a second with different versions of a GHG calculator; and a third with diverse information on international commitments, national policies and institutional information related to climate change. The microsite within IDEAM $^{\mathrm{xvii}}$ provides access to the National Communications on Climate Change, policy documents, a limited inventory of adaptation projects in the country and information on organizations and agencies that work on climate change. This microsite also has an area dedicated to children with didactic games about 
climate change. Finally, there is a Colombian Environmental Information System ${ }^{\text {xviii }}$, also managed by IDEAM, that includes simplified information on climate change extracted from government reports and policy documents. Despite government efforts to publicize technical information and policy documents, all governmental sites have technical problems, with nonfunctional links and outdated information.

Regardless of the channel, communication from the government is generally technical and uses a language that is confusing to the regular citizen. As Moser \& Dilling (2011) have discussed, knowledge alone is not sufficient to motivate action, and the science behind climate change is of small interest to the majority of audiences. Governmental speeches, documents and websites in Colombia are limited to describing measures to mitigate and adapt to climate change and to defining policies and actions from the governments and public agencies. In this manner, they alienate the individual from his/her responsibility. The governmental strategies to communicate climate change may trigger actions when conveying new regulations on the productive sector, but these strategies fall short in facilitating acceptance of regulations or in stimulating grass-roots action, which are crucial roles to encourage low carbon lifestyles, according to Ockwell et al. (2009). More importantly, although the biggest amount of knowledge that Colombia generates and communicates on climate change originates from the national government, a large gap remains between this information and decision-making.

Case study: National Communications to the United Nations Framework Convention on Climate Change (UNFCCC).

Colombia submitted its first and second National Communications (NCs) to the UNFCCC in December 2001 and December 2010. The country is expected to complete the third communication in the first half of 2017. The manner in which these documents were 
developed and communicated is a good example of the evolution in governmental climate change communication. NCs are built by IDEAM and are funded with resources from the Global Environment Facility, channelled through the United Nations Development Programme (UNDP). Therefore, these organizations, in addition to the MADS, are involved in product design, construction and communication.

First communication: A USD 345,000 United Nations Development Programme/Global Environment Facility (UNDP/GEF) grant funded the development of the First NC. Although the project objective explicitly mentioned that the exercise was essential "to enhance general awareness and knowledge of climate-change related issues in the Republic of Colombia" (UNDP/GEF, 1999), none of the project components aimed to disseminate the final document or to create communication pieces that could reach nontechnical audiences. The final product delivered was a technical report that followed UNFCCC guidelines, but no evidence of any impact on media or in the general public was observed. The document included recommendations for the construction of future NCs. However, these recommendations did not refer to gathering information or perceptions from the general public, or to generating communication materials and strategies to engage the general public in actions towards climate change mitigation or adaptation. References to communication within the document were limited to a mention of the need to improve information fluxes amongst research institutes.

Second communication: Funded through a USD 405,000 UNDP/GEF grant ${ }^{\mathrm{xix}}$, the Second NC delivered a technical document that evolved from the first NC. The document contained more accurate information and targeted technical audiences. The document was communicated to the press, and received some attention, with short notes included in a major national newspaper (El Tiempo) and an important regional newspaper (El Colombiano). No 
evidence was found of a communication strategy that engaged the general public in providing information for the report or in delivering calls to action that built on the results of the NC 1 .

Third communication: Expected to be delivered in the first semester of 2017, the development of the Third NC was funded through a USD 2,000,000 UNDP/GEF grant. The exercise has involved strategies to gather information from the general public, as well as to communicate results in a language that is more accessible to non-technical audiences. The results of the NC have been released by topics as they are produced. Climate change scenarios were the first batch of information published in March 2015 and was followed by the Green House Gas Inventory published in May 2015.

The pieces of the Third NC that have been released are translated into less technical jargon through infographics and press releases. In addition, climate change models were run at both the national and regional levels, creating more opportunities for the information to influence decision-making. Interestingly, the warm ENSO event of 2015 triggered the attention of the media on the $\mathrm{NC}$, and information relating to the country's vulnerability to climate change was eagerly publicised.

Table 1. Evolution of communication strategies to gather information for and to convey information from the National Communications in Colombia to the UNFCCC.

\begin{tabular}{|l|l|l|l|}
\hline & $\begin{array}{c}\text { Investment } \\
\text { (thousands } \\
\text { of USD) }\end{array}$ & $\begin{array}{c}\text { Communication } \\
\text { strategies to gather } \\
\text { input from the general } \\
\text { public }\end{array}$ & $\begin{array}{c}\text { Communication } \\
\text { strategies to inform } \\
\text { results to the general } \\
\text { public }\end{array}$ \\
\hline $\begin{array}{l}\text { First National } \\
\text { Communication }\end{array}$ & 345 & No evidence & $\begin{array}{l}\text { Delivery of official } \\
\text { communication to } \\
\text { UNFCCC }\end{array}$ \\
\hline $\begin{array}{l}\text { Second National } \\
\text { Communication }\end{array}$ & 405 & No evidence & $\begin{array}{l}\text { Delivery of official } \\
\text { communication to } \\
\text { UNFCCC }\end{array}$ \\
\hline
\end{tabular}




\begin{tabular}{|l|l|l|l|}
\hline & & & $\begin{array}{l}\text { Media launch. Poor } \\
\text { reception (two major } \\
\text { newspapers, short notes) } \\
\text { Children's story } \\
\text { targeting highland, } \\
\text { páramo populations } \\
\text { Executive summary for } \\
\text { teachers }\end{array}$ \\
\hline $\begin{array}{l}\text { Third National } \\
\text { Communication } \\
\text { (up to August } \\
\text { 2016) }\end{array}$ & 2,000 & $\begin{array}{l}\text { Survey on perception of } \\
\text { vulnerability } \\
\text { Regional workshops } \\
\text { Communication pieces } \\
\text { built by local } \\
\text { communities }\end{array}$ & $\begin{array}{l}\text { Special issues about } \\
\text { GHG inventory in two } \\
\text { main newspapers } \\
\text { Fractioned } \\
\text { communication of the } \\
\text { report, dedicated to each } \\
\text { topic } \\
\text { Less } \\
\text { infographics technical }\end{array}$ \\
\hline
\end{tabular}

The development and outreach of NCs exemplify the incorporation of communication strategies in gathering useful information from communities and focus groups. The evolution of the NCs also exemplifies how the government could be paying more attention to making information available to the general public, by producing communication materials and channels that target non-technical audiences. The mainstreaming of approaches like the ones used in the Third NC is still to be determined, and their effectiveness is still to be studied.

No current studies analyse the evolution of governmental communications in Colombia. Since the government is the primary source of the information that finally reaches the general public, determining whether messages are triggering actions from citizens is important, particularly considering the country's ethnical and biological diversity and its influence in mitigation and adaptation.

\section{Climate change in academic communication in Colombia}

Colombia is a country with relatively high academic production in Latin America. Scopus data show that scientific production has risen considerably in the country over the past 50 
years, with only 10 outputs published in 1965 and nearly 7,000 outputs published in 2015 (Fig.1a, source: Scopus). The number of scientific outputs related to climate change published by Colombian researchers in English-language academic outlets also have increased ten-fold between 2005 and 2015 (Fig.1a, Fig. 1b, source: Scopus). Outputs related to climate change are those that contain the words "climate change" in the publication title, abstract or keywords. Beyond Scopus and other recognized databases, an important catalogue for Spanish-language outputs is the Scientific Electronic Library Online (SciELO). SciELO is an open-access scientific database that aims to overcome distribution and dissemination barriers faced by scientific journals from Latin American and Caribbean countries. A SciELO search for "cambio climatico" in the title and abstract fields revealed that Colombia-affiliated scientists have published 45 academic outputs since 2010 (source: SciELO). This figure does not include academic outputs that were included in the Scopus search. The results obtained here from the Scopus database are comparable to those presented by IDEAM (2016). IDEAM (2016) additionally reports low citation numbers of climate-change related outputs produced by Colombian researchers, suggesting that the potential of this knowledge to be communicated beyond academia may be even lower. 


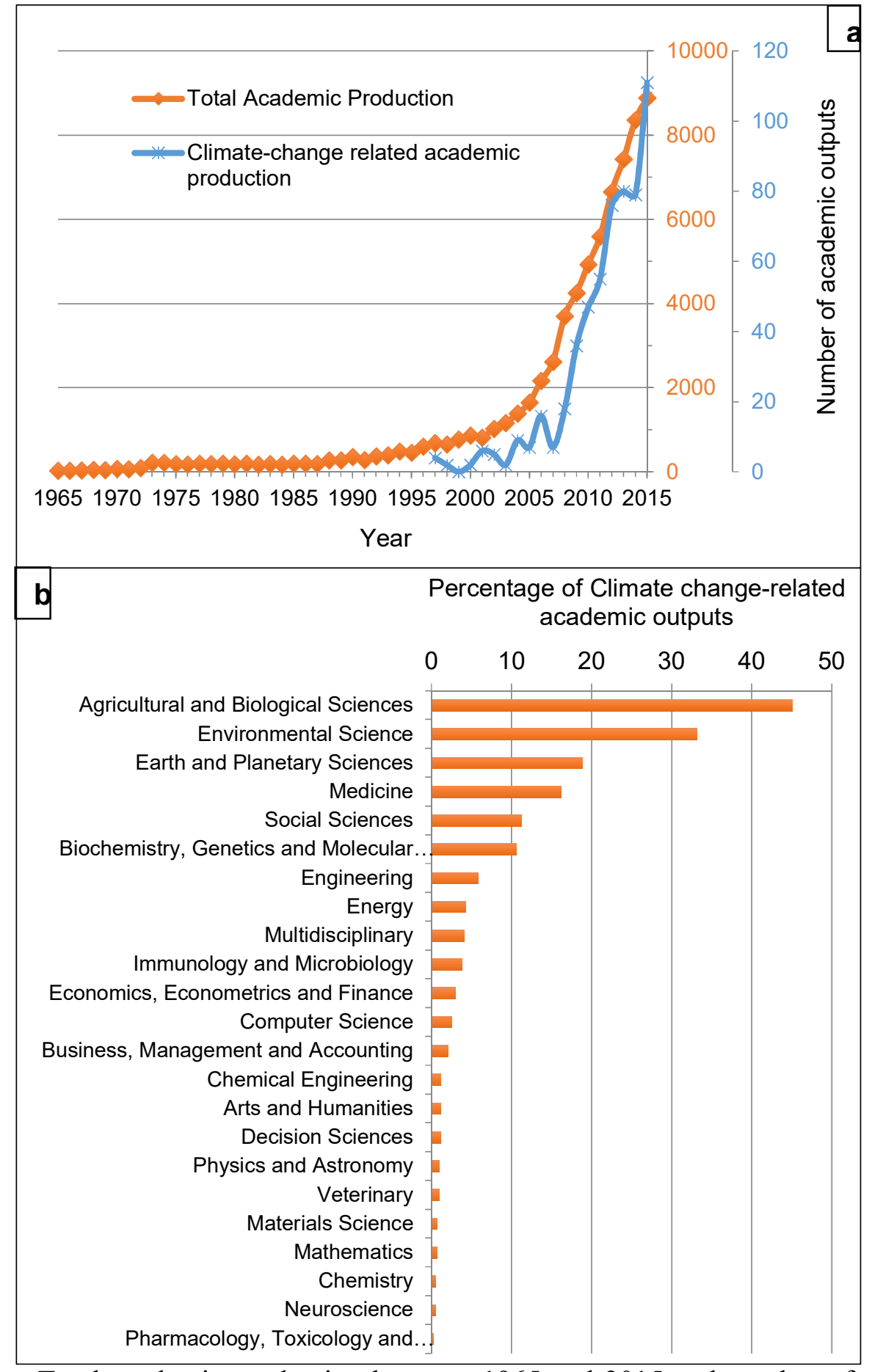

Figure 1. a: Total academic production between 1965 and 2015 and number of scientific outputs that contain the phrase "climate change" in the publication title, abstract or keywords and that have been published by Colombian-affiliated researchers in English-language academic outlets between 1997 and 2015 (source: Scopus). b: Percentage of outputs related to climate change by subject area. 
Despite the relatively strong climate change research in Colombia, academic products are seldom disseminated and communicated in a manner that is easily understood by decision makers and has a clear influence on public policy. The comparison between academic outputs published in English vs. Spanish scientific outlets suggests that Colombian scientists are far more inclined to publish their scientific products in English. This language difference poses a potential problem for climate change communication of academic production to the media, decision and policy makers, and other stakeholders.

Some academic findings are incorporated into reports intended for Colombian policy makers despite the language challenge. This practice consequently increases the potential for these findings to have a significant impact on decision-making. For example, research conducted by the International Center for Tropical Agriculture (CIAT) on food security and climate change (Jarvis et. al., 2010) was incorporated into a white paper intended for policy makers and presented a vulnerability assessment of agricultural systems and water resources in the Andean region of Colombia (CIAT, 2013). Such an assessment is one of the outcomes of the project "Regional Portal for Technology Transfer and Action against Climate Change in Latin America and the Caribbean" from the United Nations Environmental Program. The CIAT (2013) report outlines the potential expansion of agricultural areas under current climate change; in particular, the potential expansion of high-altitude potato production areas into the páramo ecosystem as a result of global warming. The report also calls for strengthening policy around parámo conservation areas and for the design and implementation of payment schemes for ecosystem services.

The existence of white paper documents such as the document produced by CIAT (2013) shows that some effort has been made by research institutes to translate relevant 
academic findings into documents intended for non-scientific audiences. CIAT (2013) in particular often produces white papers that outline policy-relevant climate-change information and acknowledges the participation of members of the Ministry of Agriculture and Rural Development, the National Planning Department, and the National Meteorological Institute. Recognizing the participation of these governmental bodies suggests that research institutes like CIAT engage in an active dialog with policy makers.

Despite these examples, the practice of translating academic findings into white papers is not widespread in Colombia. Colombian higher education institutions or universities offer little incentives for researchers to engage with the general public (as suggested for other countries in Moser, 2010). Consequently, a large portion of climatechange research produced by university-based researchers remains in the scientific journals and has minimal influence on decision or policy making. When a dialogue happens between policy makers and academics, it is often initiated by the researcher. Academics make use of government documents and reports to inform their research activities (e.g., Cadavid \& Ospina, 2013). However, government officials seldom seek the advice or knowledge that academics can offer, unless a technical justification for a bill is needed. We found little evidence that policy makers consult the academic literature, perhaps because they are challenged by the specialized language.

\section{Case study: Environmental risk management and academia in Medellín}

An example of a powerful cooperation between policy makers and academia involves the climate change risk management system for the Aburra Valley. The Aburra Valley is where Medellín is located, the second largest city in Colombia. Medellin produces approximately $23 \%$ of the country's GDP (source: DANE), and its investment in risk management between 2002 and 2008 averaged COP 14,712 per capita, or approximately 
USD 5 in Sep 2016 (Campos et. al., 2011). Risk management in the Aburra Valley is largely steered by the Early Warning System for Medellin and Aburra Valley (Sistema de Alerta Temprana de Medellín y el Valle de Aburrá, SIATA). SIATA is a science and technology project created within the metropolitan authority that is also supported by the regional public water company (Empresas Públicas de Medellín) and a private electricity company (ISAGEN).

SIATA an example of a productive collaboration between the government and academia, where communication with the general public is of paramount importance. The project is led and operated by a group of climate experts formerly or currently affiliated to local universities, along with computer scientists and physical engineers. SIATA manages early response systems to an array of environmental risks in the Aburra Valley. These risks include earthquakes, floods, landslides, and, recently, air quality.

Currently, SIATA focuses on air quality as it is one of the most tangible environmental risks in the city of Medellin, but the project and current communication strategy are already in place and could be readily used for climate-change related environmental risks. Over the past 5 years, air quality has gained attention as an important environmental risk in Medellín due to an accelerated increase of air pollutants. Reduced air quality in the Valley is linked to three main factors: topography, localised fires and vehicle pollution. Topography restricts the exit of air pollution from the valley due to steep slopes and narrow inlets and outlets, while localised fires inject large quantities of pollutants into the atmosphere over short periods of time.

SIATA and the Metropolitan authority have developed a communication strategy that intends to educate the general public about meteorology and air quality. The strategy includes a citizen science initiative where citizens take real-time measurements that are later 
incorporated into air quality estimates. In this way, citizens are encouraged to take responsibility for the improvement of air quality, by using public transport, car sharing or alternative means of transport, such as bicycles. SIATA also uses social media as part of its communication strategy. Their Twitter account (@siatamedellin) has 13,300 followers who are updated on weather conditions, increases in river flow and flood risks, and citizencollected air quality data. Finally, Clima $24 / 7$ is a television program broadcasted on the regional television channel as part of the Medellín Metropolitan authority's communication strategy. Clima 24/7 disseminates messages related to weather, global events, such as ENSO, and the effect of weather and atmospheric conditions on public health (http://clima247.gov.co/).

Quantitative measures are not currently available to assess the efficacy of SIATA's communication strategy. However, public awareness on air quality issues has increased considerably over the past year. While the communication strategies for risk management in Medellín are still too recent to allow the assessment of their success, they do illustrate the potential of citizen engagement in climate change communication in Colombia. SIATA, with its roots on government-academia collaboration, has shown to be successful in disseminating information on meteorology and air pollution. These mechanisms and communication strategies are already in place and could be used to disseminate information and manage environmental risks linked to climate change in the Aburra Valley.

\section{Climate change in the Colombian media}

Television, particularly the news, is the most consumed medium in Colombia, as explained in section Overview of knowledge on climate change communication in Colombia. Both science and "natural" disasters have to be included when analysing the relation between media and climate change communication in Colombia. Arboleda et al. (2011) and Hermelin 
(2013) have observed that during discussions of ENSO (which combines El Niño and La Niña events), the media indistinctively use expressions such as "warm season" (temporada de calor), "drought season" (temporada de sequía) or "heat wave" (ola de calor) when referring to El Niño, and "rainy season" (temporada de lluvias), "winter season" (temporada invernal), "winter wave" (ola invernal) or "rainy wave" (ola de lluvias) when referring to La Niña. In addition, the media -particularly television news, refer to climate change either as something similar to El Niño or La Niña events or as if these events are the cause or consequence of climate change. As described in Overview of knowledge on climate change communication in Colombia, sources and testimonies used by the Colombian media to treat El Niño do not originate from researchers or climate experts (Arcila et al. 2015a, Arcila et al. 2015b, Zamith et al. 2012, and Arboleda et al. 2011). This is particularly relevant because it has taken time and research for Colombian scholars to refer to direct correlations between ENSO and climate change (Ochoa, 2016); however, the media often "naturalize" these correlations. In discourse analysis this naturalisation corresponds to the didactité effect (Moirand, 1997): when a subject is mentioned repeatedly by the media, it is assumed that this subject is comprehensible for the audience. In this case, when media repeat the correlation between ENSO and climate change, the audience will assume such a correlation is an indisputable fact ${ }^{\mathrm{xx}}$.

The didactité effect is a recurrent trait in the manner that the Colombian media address "natural" disasters (Hermelin, 2007). In fact, when insisting on naming them disasters and using the adjective "natural", the anthropogenic causes and responsibilities are omitted. Media even use expressions, such as "divine punishment" or "the Earth is alive", with which journalists contribute to the reinforcement of such an omission, oftentimes unintentionally. The use of the adjective "natural" when referring to disasters deserves a 
special note, particularly considering that the majority of human losses during disasters in Latin America are related to hydrometeorological phenomena that can arguably be related to climate change (as suggested by Garcia Acosta, 2008). By attributing disasters to a higher force, media miss the opportunity to refer to preventing the harmful effects of climate change and contribute to making mitigation and adaptation a part of the citizen agenda.

\section{Case study: Climate change in Noticias Caracol}

The studies of Arboleda et al. (2015) and Arboleda et al. (2011) provide an interesting case to illustrate climate change communication in the Colombian media. Both studies analyse productions from Noticias Caracol, the prime time television news program with the largest audience in Colombia. The first corpus (raw information from the broadcasts) includes 6-moth data from April 2009 to March 2010, and the second corpus includes oneyear data from September 2009 to March 2010. Both are based on a protocol explained in detail by Massarani \& Ramalho (2012), which aims to identify news related to scientific research with proposals of science outreach and science policy. The sample used the methodology of constructed week sampling (Krippendorff, 2004). None of the studies found a large number of references related to climate change, and the majority of television news broadcasts were linked to the Copenhagen UNFCCC COP15 in December 2009. The results confirm that sources are mostly political and rarely scientific, which was already identified by Arcila et al. (2015b) when analysing media responses to four different international summits, including COP15. This tendency is common in other countries, as presented by Painter (2011) in a comparative study of media in six countries. Interestingly, the Copenhagen COP15 was an important influence on the Colombian media agenda, and this impact was greater than in previous and following COP. The data show that climate change 
was on the media agenda, but such an agenda did not take into account discourses from PCST perspectives.

Between April 2010 and April 2011, Colombia experienced the effects of one of the strongest La Niña events ever registered. Victims were estimated to be over 3.2 million (7\% of the population) $)^{\mathrm{xxi}}$, according to official sources. The television news program Noticias Caracol dedicated the most time to this long event and even developed a campaign to support victims as part of its Corporate Social Responsibility strategy. The government made a call for public and private resources to create the National Fund for Disaster Risk Management, and established two different funds for the immediate and long term attention of the disaster (Colombia Humanitaria and Fondo Adaptación, respectively). The risk management system was modified, creating the National Unit for Disaster Risk Management (in lieu of the National Office for Disaster Prevention). Media, government, the private sector and society had the same agenda: a strategy to face these phenomena, mitigate their effects and adapt to them. However, media, in particular Noticias Caracol, insisted on using climate change as a synonym for La Niña phenomenon. This case exemplifies how the interest of media to communicate climate change does not necessarily trigger the interest of media to understand climate change; including issues on the news agenda does not mean that media and audiences will have a better comprehension of them, or more information to contribute to adaptation, mitigation, and risk management.

In conclusion, political sources prevail in Colombian media (Arboleda et al., 2011, Arboleda et al., 2015, Arcila et al., 2015a, Arcila et al., 2015b, and Zamith et al., 2012). At the same time, some of the media agendas lack scientific sources, do not help to strengthen ideas of scientific controversy, and dramatize subjects that can be related to climate change issues (Hermelin, 2007, and Arboleda et al., 2011, and Hermelin, 2013, in Colombia, and 
O’Neill \& Nicholson-Cole, 2009, in a more general context). Media may not have all the power to drive the Colombian citizen agenda, but they do have a privileged position to influence such an agenda (Bonilla et al., 2012). What happened between April 2010 and April 2011 calls for more complex approaches to the relation between the media and the environment and, in particular, to media's role in climate change communication in Colombia. The latter should raise the interest of disciplines that may range from Communication Studies, PCST, SST to Risk Sociology. The task is complex and demanding but is a priority. Colombian media have important contributions to make to reduce the consequences of climate phenomena related to climate change and whose anthropogenic causes must not be omitted. For this purpose, the media should approach other actors, particularly government, academia and NGOs, not only to improve their sources of information but also to build stronger critical abilities in their role as climate change communicators.

\section{Non-governmental organizations (NGOs) and Climate Change Communication}

NGOs have engaged in efforts to communicate climate change in Colombia and have attempted to prioritize climate change on the country's development agenda. Because of their nature, these tasks pose the challenge of engaging a diverse set of communities and the public.

Colombian NGOs share general NGO characteristics and communication strategies, which include: 1) they have legal standing; 2) they are non-profit associations; 3) they cooperate with other audiences such as government, media, and academia to gather resources, media coverage or political recognition; 4) their main objectives are social or environmental in nature; and 5) they are a key channel for the general public to make their voices heard. In other words, NGOs are a platform for the general public to connect with other persons or 
institutions who share similar beliefs, ideas, values, and convictions (Arroyo \& Martin, 2011). When communicating, NGOs not only have to consider their objectives, but at the same time they must find sympathetic donors to be able to continue their work.

Environmental NGOs also have an additional intrinsic characteristic: they are perceived as trusted and credible (O’Neill \& Nicholson-Cole, 2009), independent from the interests of politics and the private sector. Communications should then be a delicate, important element in an environmental NGO strategy; nonetheless, the majority of NGOs are not experts in communicating their issues, activities and mission (Arroyo \& Martin, 2011).

Because of the manner in which NGOs need to constantly address different geographic, cultural, political and environmental contexts, their experience in communicating climate change is important, given the paucity of research on the matter in Latin America. The issue has not been studied in Colombia, but publications from similar contexts are available. Arroyo \& Martin (2011) explored climate change communication strategies of 26 NGOs in Argentina and Spain, using public recognition and international/national work as criteria for selecting the organizations. Surveys and interviews with communication directors or staff revealed that $80 \%$ of NGOs had a communication department, but only $37 \%$ of those had a media plan or communication strategy (Arroyo \& Martin, 2011). Organizations that did have a communication strategy did not consider which audiences or publics were most important for their work or what channels were most effective for impacting their donors, and the mission of their strategy was to find resources.

In the case of online presence, at least $90 \%$ of the organizations in the study had a webpage, but did not upload new information or content about their issues on a regular basis. Furthermore, social media strategies (Facebook, Twitter, LinkedIn) were non-existent, particularly in Argentina. NGOs had social media accounts, but little new content was being 
shared (Arroyo \& Martin, 2011). The authors recommended that NGOs use internet platforms to reinforce the links they have with communities and that they share content about what they do, how money is invested and their views on their organization's mission to raise the visibility of their work and to show how communities can support their cause (Arroyo and Martin, 2011).

In addition, some NGOs have effectively used communication strategies to promote their issues. Greenpeace, an organization that has been active in Colombia since 2009, is one of these examples. The organization has five strategies for achieving its goals: scientific reporting, government lobbying, working with industries, providing information to academia and media, and producing public campaign literature (Doyle, 2007); therefore, communication is a strong element in their efforts. The Greenpeace communication strategy has two main goals: to document environmental destruction and to convey the visual beauty of nature at risk through non-violent direct actions (Doyle, 2007). Since 1974 this international NGO has investigated and communicated the consequences and risks of climate change to a broad audience, and climate change was the issue they used in their opening campaign in Colombia. The organization has a centralized media plan, and all materials, pictures, slogan, and colours must be approved by Greenpeace's international office (Doyle, 2007). According to Doyle (2007), Greenpeace performed well in drawing attention to climate change but has reduced it to a single moment: that photo, that day. Greenpeace has had to "work against time" to make climate change meaningful as a real and present threat before its impacts can be seen. To the organization's credit, an examination of the history of its climate change communication reveals that Greenpeace has always sought to present climate change as a current threat (Doyle, 2007). The invisible nature of climate change has 
proven difficult to communicate (Doyle, 2007), but Greenpeace's communication materials have helped to explain and illustrate the effects.

In Colombia, Greenpeace has a campaign to protect páramos. These high-altitude ecosystems are responsible for providing water resources to urban areas and provide habitat for 4,700 plant species (Greenpeace, 2016) but are highly vulnerable to climate change. If temperatures rise, as is expected in current climate change scenarios, key species will disappear, which, in turn, will impact hydrological regulation (Greenpeace, 2016). To communicate this relationship, Greenpeace staff write reports about climate change consequences on moor ecosystems, posting shocking or beautiful pictures on Facebook and Twitter, constructing social media campaigns, and publishing videos that illustrate the dangers of mining and agricultural activities in páramos.

In contrast to Greenpeace's strategy, other NGOs have used a scientific approach to communicate climate change. In this model, the NGOs believe that public is in need of education from experts (Nerlich et al., 2009; Schäfer \& Schilictin, 2014). Knowledge and consensus are assumed to increase as a result of more effective public engagement on the part of scientists (Nerlich et al., 2009), and people are expected to take actions to mitigate their contribution to climate change. In Colombia, climate change communication often takes the above-mentioned scientific approach. Environmental NGOs that use a scientific approach commonly produce and publish reports that are coherent and compelling and describe research results. These NGOs also produce digital pieces such as videos and Facebook posts, to generate dialogue on the web. However, the language used often uses technical jargon.

This science approach may present climate change in a manner that is complex for the general public, despite the fact that the public must be the primary actors against climate change (Schäfer \& Schilictin, 2014). Corner \& Groves (2014) also observed that improved 
scientific literacy can actually increase polarization rather than consensus in ideologically opposed groups, since the individual assimilates knowledge to climate change though his/her ideas, values and perspectives. The authors note that, even if the scientific approach advanced a simplified message, the approach would finish in a deadlock, because a fundamental tension exists between the scientific approach and the social institutions that make decisions.

The degree to which the Colombian public accesses academic production has not been quantified. However, increase in scientific production observed in Colombia over the past 15 years (Fig. 1a) has had little effect on GHG emission reductions or climate change mitigation. Nerlich et al. (2009) noted that climate change communication must move from one manner of communication to dialogue and reflexive engagement. The scientific communication "recipe" needs to shift from "one size fits all" to a "tailor made" approach for specific people. NGOs' climate change communication should be a bridge between scientific and government approaches and the general public. This involves cognitive, affective, and behavioural dimensions; people grapple mentally with and gain understanding of the issue, experience an emotional response, such as interest, concern or worry, and respond by way of changes in climate-relevant behaviour or political action (Moser \& Dilling, 2012). In other words, climate change communication success is based on how well it achieves public engagement.

Because of their proximity to the public, NGOs have a better opportunity to convey climate change using a customized model, where the audience is the most relevant driver instead of the message itself. According to Moser \& Dilling (2012), understanding which audience is going to receive the message, what the audience knows about climate change, what channels the audience uses to inform itself, which messengers are credible, and what the audience believes in will allow communicators to create a successful message. The closer the message is to audiences, the greater the probability of generating actions. 
In Fiji for example, one strategy was to place a high value on oral narratives. This action facilitated the spreading of key messages to the communities in a way that was more effective than internet information, workshops or meetings, because oral narrative were and are part of Fiji's cultural values (Janif et al., 2016). In an experiment conducted in the United Kingdom, diverse individuals participated in focus groups designed to evaluate the impact of both climate change visual images and actions for fighting against climate change (O’Neill \& Nicholson-Cole, 2009). The results indicated that images similar to their communities and neighbourhoods empowered them to do something about climate change. On the other hand, photos of disasters in other regions of the world, even the ones that are representative of the issues such as floods or droughts, gave them a sense of helplessness, remoteness and lack of control (O'Neill \& Nicholson-Cole, 2009). This idea is supported by the theory of how people learn; Vella (2002) cites 12 principles to which a professor or facilitator must adhere to make people learn something new, based on the immediacy of the learning, praxis, and ideas connected with feelings and actions, and not on the content itself. "We know that learning involves more than cognitive material (ideas and concepts). It involves feeling something about the concepts (emotions) and doing something (actions)" (Vella, 2002 p 18). In addition, a study in the United Kingdom ascertained that one of the largest barriers to people mitigating climate change was that they were not engaged with the issue, as information and hard data are not sufficient to have citizens motivated and able to take action (Lorenzoni et al., 2007). Then, it is not an overstatement to say that it is necessary that climate change communication seeks to connect more with peoples' hearts and actions.

Another concept that should be applied to climate change communication is the importance of the language choice to transmit ideas. Words, adjectives and stressing certain concepts make a difference. In mass media, language about climate change is urgent, 
apocalyptic and beyond human control (O’Neill \& Nicholson-Cole, 2009). Alternatively, metaphors could be used to bring climate change closer to people; words and their meaning can be the difference between positive or negative ideas.

Connecting to people's feelings and choosing words appropriately could help improve communication in the mission to encourage action on climate change. Effective communication strategies are a mixture of modes, channels and audiences. As Fondo Accion's climate change communication strategy shows, NGOs experience a significant challenge when they are faced with such diversity. This is particularly relevant in a country such as Colombia, where high biological, geographical and cultural diversity adds an extra layer of complexity to the development of climate change communication strategies.

\section{Case study: Fondo Accion's climate change communication strategy.}

Fondo Accion is an example of an NGO approaching climate change communication in alternative ways. Fondo Accion was founded in 2000 as a private non-profit organization with the objective of managing and executing the resources that Colombia had gained through a debt-for-nature swap with the United States. The NGO has grown beyond the administration of these funds and currently has approximately 20 donors.

In Fondo Accion, climate change projects are based on the premise that moving hearts and creating awareness leads to action. Regular news reports and statements are framed by hopefulness regarding the consequences of this phenomenon. This approach challenges the traditional idea of delivering information as facts and enables a different perspective on learning (Vella, 2002). The process for generating campaigns, messages or communication strategies on climate change begins with a multidisciplinary analysis. This analysis consists of a discussion between the communications team, professionals from each environmental project and the public policy area. The multidisciplinary team jointly examines the 
information to be communicated (Fig. 2). The team also examines how, to whom, what for and the goals they want to be achieved with the message. Depending on the project, other government organizations, NGOs, private companies or children groups may be invited to participate in the dialogue and the construction of the campaign. The innovation that results from interdisciplinary and interinstitutional teams has been a lesson learned by Fondo Accion. A first step in the interdisciplinary work is to ensure that the needs from each area are identified and the objectives are stated. Needs, objectives and expected results may be determined by the individual project and can generate calls for action from a particular audience or activate conversations and dialogue on policies. Once needs and objectives are identified, the options for addressing these needs are proposed by the multidisciplinary team, allowing the different visions for a common goal to converge. The presentation of competing arguments allows for a greater richness in the campaigns and, most of all, a broader and more comprehensive look at the situation.

An important moment of the exercise is to synthesize a key or umbrella message: the focus of the communication campaign. One of the lessons that Fondo Accion has learned is that this key message must meet three objectives: be sexy, give a general and clear idea of what is to be transmitted, and cover most of the issues that may rise in the framework of the campaign. Additionally, the team considers to whom the message should be addressed. The question becomes relevant when considering that the audiences are active subjects in the campaign: they work on improving their ability to share their points of view live and instantaneously due to social networks and other technological advancements. This allows for placing oneself in the audience's shoes, getting out of the traditional roles in which one works and imagining how the audience will react when receiving the contents, materials or information. Once the requirements of the communication strategy have been defined, 
responsibilities are assigned, and the schedule and budget are prepared. Strategies are revised regularly during the length of the projects to adjust them to the evolving contexts. Community workshops, regional or national events, puzzles, songs, poems, manuals and policy papers are some of the alternatives that give life to each action. This approach allows the NGO to learn with the communities. Additionally, other institutions that work with relevant topics also are engaged in the dialogue. This way, knowledge is not one truth that is unidirectionally provided, but an exercise of reflection, change and transformation in which different actors participate and have a voice.

As a tangible example, to communicate climate change in the Chocó region of Colombia, the organization connects to the river, the forest, and the community that inhabits the area as key elements. In contrast, in the Amazon region connection is more closely related to farming, indigenous legacy and the forest. This audience classification allows communication teams to think of products and materials of diffusion that are appropriate for each audience and is a particular benefit of multidisciplinary teamwork. "Identification requires that we forget ourselves and become the other-that we assume for ourselves the identity of the target of our identification" (Cohen, 2001, p 247). This practice has an implicit value: it recognizes that the audience is not naïve (Ottaviani \& Squintani, 2006) and acknowledges that the communication process is multidirectional.

Fondo Accion has learned that the efforts of creating the best and most effective campaigns are born in teams, the NGO must also seek advice from experts, and from the people who live the problems and consequently generate ideas to solve them. Empathic listening is one of the qualities that helped this NGO to enhance its projects. This concept or ability seeks to transform the way humans communicate. The premise behind this concept is that listening and asking the correct questions is even more useful than the answer (Covey, 
1990). For NGOs, the ability to listen enables to identify the needs, expectations, and concerns of a community. This approach also allows NGOs to take into account the type of territory a community inhabits and the type of resources they have. Most importantly, this approach allows them to listen to stakeholders instead of telling them what to do (Sirolli, 2012).

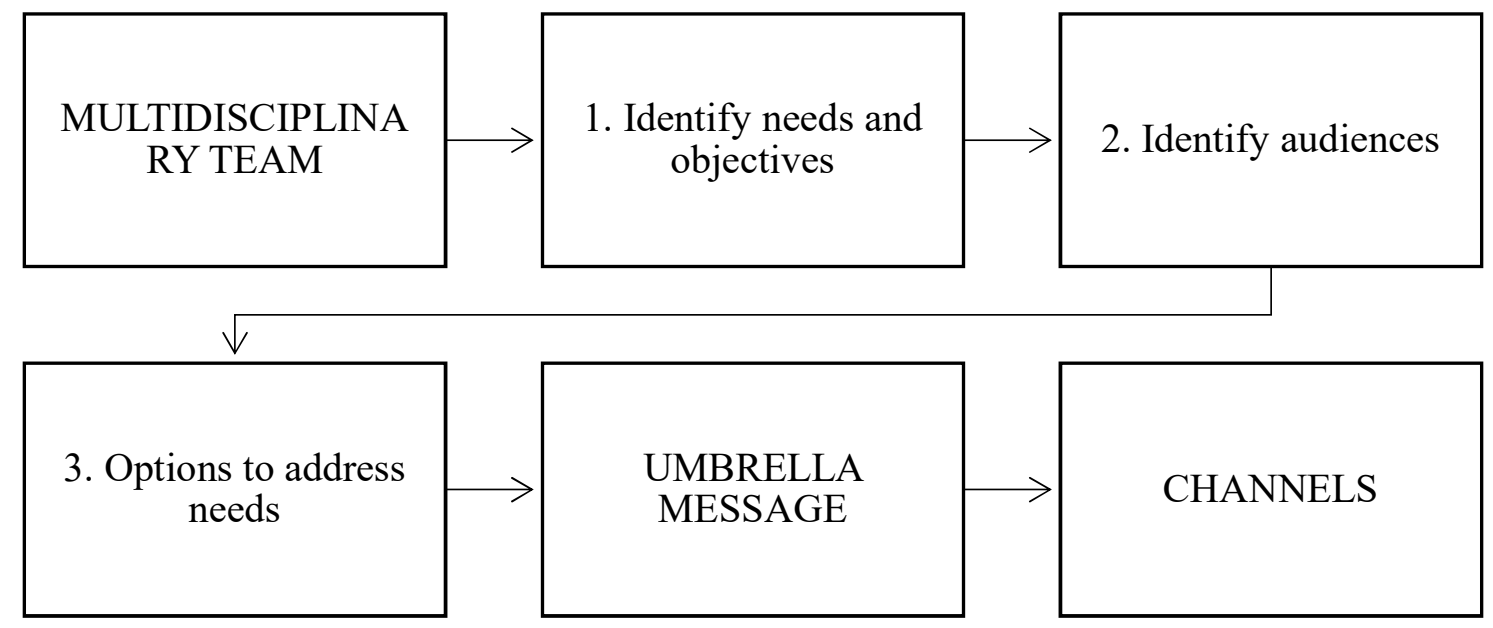

Figure 2. Communication strategy from Colombian NGO Fondo Accion. Chart developed using Piktochart ${ }^{\circledR}$

\section{Conclusion}

The characteristics and evolution of climate change communication in Colombia still are not well known. Studies that examine the issue are scarce. However, the current evidence reveals a lost opportunity in triggering actions and decisions from the general public and decision makers. A close but non-effective connection is present between the media, the source of information for most Colombians, and the government. While the media uses the government as the main source of information, the government communicates in a technical fashion that addresses the needs of the international agreements but not its own needs to 
stimulate adaptation and mitigation. Therefore, neither the government, nor media, as its voice, generate calls for actions or decisions from the respective stakeholders.

This relationship is not filtered by academia, where the production of publications is growing but where only small efforts have been made to translate scientific language to communications that are accessible to the general public and that gather the attention of media. Media also look for experts more often in the government than in academia, likely seeking charismatic rather than knowledgeable personalities. The relation is also not filtered by NGOs, who have a tendency to generate communication material for their direct use with communities and projects on the ground. The NGO sector produces more customized communication material than other sectors, with strategies that consider cultural, institutional and environmental contexts.

These conditions generate at least three communication shortcomings. First, the sector that generates the most knowledge is not the one whose communications influence decision-making or citizen action. Second, the government is communicating technical facts in a fashion that does not contribute to its own mission of generating change in social and economic decisions. Third, rather than creating a learning process for the general public, the media may be leading their audience into a cycle of confusion on climate change issues. Customized approaches applied in the NGO's communication strategies may fall out of such cycle of confusion.

Advancing the research agenda on climate change communication in Colombia is important to critically contribute to communication's improvement. Research should look deeper into climate change perception, for instance i) independently estimating the percentage levels of climate change understanding in the Colombian public; ii) assessing the efficiency of the messages that emerge from the government and academia; and, iii) 
translating the communication strategies generated by NGOs into models that can be used by other practitioners. Such an agenda should understand the gaps that do not allow different sectors to trigger actions from the general public. Research should also investigate how climate change could be integrated in the media agenda and analyse whether governmental, academia and media communication strategies could benefit from learning about the NGO approach and be more assertive in triggering actions. Understanding the challenges of climate change communication in Colombia necessitates a grasp of the country's extremely rich and diverse characteristics; the need to address communication differently in the country's context would become evident through a comparative analysis between climate change communication in other countries and in Colombia. Ethnic, cultural and biogeographic settings may vary in Colombia within very short geographical distances. This variability should dictate the risks, opportunities and approaches for climate change communication.

\section{Acknowledgements}

The authors would like to thank Saffron O’Neill and Lee Oglesby for the invitation to participate in this encyclopaedia. We would also like to thank Gabriella Restrepo and Susana Galvis, Communication students at Universidad EAFIT (Medellín-Colombia) for their support in searching some resources for the text. We are also grateful to Jonathan Dain, from the University of Florida Center for Latin American Studies, for useful comments on an earlier version of a section of the manuscript.

\section{References}

Allison, E. H., Perry, A. L., Badjeck, M.-C., Adger, W. N., Brown, K., Conway, D., . . Dulvy, N. K. (2009). Vulnerability of national economies to the impacts of climate 
change on fisheries. Fish and Fisheries, 10, 173-196. doi:10.1111/j.14672979.2008.00310.x

Alongi, D. M. (2012). Carbon sequestration in mangrove forests. Carbon Management, 3, 313-322.

Arboleda, T., Hermelin, D., Massarani, L., Ramalho, \& M., Reznik, G. (2015). Ciencia y tecnología en los telediarios colombianos: entre lo que se cubre y lo que no. Ensaio. Pesquisa em Educaçao em Ciencias. 17(1), 207-228.

Arboleda, T., Hermelin, D., \& Pérez-Bustos, T. (2011). La cobertura de la ciencia en los noticieros colombianos: del análisis de resultados a las reflexiones metodológicas para su investigación. Ensaio Pesquisa em Educação em Ciências. 13(3), 151-166.

Arcila, C., Granados, J. F., \& Mercado, M. T. (2015). From COP12 in Nairobi (2006) to COP15 in Copenhagen (2009): Coverage of climate change in online SpanishSpeaking media'. [De la cumbre de Nairobi (2006) a Copenhague (2009): Cobertura del cambio climático en medios digitales en español] Cuadernos.Info. (37), 107-119.

Arcila, C., Mercado, M. T., Piñuel-Raigada, J. L., \& Suárez-Sucre, E. (2015a). Media coverage of climate change in Spanish-Speaking online media. Convergencia. 22(68), 71-95.

Arroyo, I., \& Martin, R. (2011) La utilización de Internet en la comunicación expresiva de las ONG: Estudio exploratorio comparativo entre Argentina y España. Revista de estudios de comunicación. 16 (31), 243-263.

Asner, G., Clark, J. K., Mascaro, J., Galindo García, G., Chadwick, K., Navarrete Encinales, D., Paez-Acosta, G., Cabrera Montenegro, E., Kennedy-Bowdoin, T., \& Duque, Á. (2012). High-resolution mapping of forest carbon stocks in the Colombian Amazon. Biogeosciences, 9(7), 2683-2696. 
Barkemeyer, R., Dessai, S., Monge-Sanz, B., Renzi, B. G. \& Napolitano, G. (2015). Linguistic Analysis of IPCC Summaries for Policy Makers and Associated Coverage. Nature Climate Change 6, 311-316 (published online: 12 october 2015)

BioREDD. (2015). Menos $\mathrm{CO}_{2}$, más desarrollo; $\mathrm{REDD}+$ en el Pacifico colombiano. Bogota: USAID.

Bonilla, J. I., \& Cadavid Bringe A. (Eds.). (2004) ¿Qué es noticia? Agendas, periodistas y ciudadanos. Bogota, Colombia: Pontificia Universidad Javeriana y Fundación Konrad Adenauer.

Bonilla, J. I., Cataño, M., Rincón, O., \& Zuluaga, J. (2012) De las audiencias contemplativas a los productores conectados. Mapa de los estudios y de las tendencias de los ciudadanos mediáticos. Cali, Colombia: Pontificia Universidad Javeriana, Medellín, Colombia: Universidad EAFIT, Bogota, Colombia: Universidad de los Andes.

Bouma, M. J., Poveda, G., Rojas, W., Chavasse, D., Quiñones, M., Cox, J., \& Patz, J. (1997). Predicting high-risk years for malaria in Colombia using parameters of El Nino Southern Oscillation. Tropical Medicine and International Health, 2(12), 1122-1127. Bucchi, M., \& Trench, B. (Eds.). (2014). Routledge Handbook of Public Communication of Science and Technology. Londres, Inglaterra: Routledge.

Cadavid, N., \& Ospina, J. P. (2013). ¿How to prepare the Aburra Valley to face the climate change? propositions from the BIO 2030 plan. DYNA (Colombia), 80(179), 176-185. Campos, A., Holm-Nielsen, N., Díaz G., C., Rubiano V., D. M., Costa P., C. R., Ramírez C., F., \& Dickson, E. (2011). Executive Summary. Analysis of Disaster Risk Management in Colombia: A Contribution to the Creation of Public Policies. Retrieved from Washington, DC 20433, USA. 
CEDISCOR. (1992). Les carnets du CEDISCOR (no. 1). Un lieu d'inscription de la didacticité: les catastrophes naturelles dans la presse quotidienne. Paris: Presses de la Sorbonne Nouvelle.

Centro Internacional de Agricultura Tropical (CIAT). (2013). Evaluación de la vulnerabilidad al cambio climático de la agricultura en la región Andina de Colombia. Políticas en Síntesis, 6.

Cohen, Jonatan. (2001) Defining Identification: A Theoretical Look at the Identification of Audiences With Media Characters Mass communication and society 4 (3) 245-264. Comisión Económica para América Latina y el Caribe. (2012). Valoración de daños y pérdidas. Ola invernal en Colombia, 2010-2011. Bogota: Misión BID-CEPAL.

Corantioquia. (2008). Cambio climático: ¿una caja de pandora?. Medellin, Colombia: Corantioquia. $75 \mathrm{P}$.

Corner, A., \& Groves, C. (2014) Breaking the Climate Change Communication Deadlock. Nature Climate Change 4, 743-745.

Correa, S. L. (2013). Saber, creer y hacer. Conocimiento etnoclimatológico en Providencia y Santa Catalina, Caribe insular colombiano. PhD disertation. Facultad de Ciencias Sociales y Humanas. Universidad de Antioquia, Medellín, Colombia. (Advisor: Sandra Turbay).

Covey, S.R (1990) Principles of empathic comunication The 7 habits of highly effective people. Simon and Schuster, New York.

Daza-Caicedo, S. (Ed.). (2009). Percepciones sobre la ciencia y la tecnología en Bogotá. Bogota, Colombia: Observatorio Colombiano de Ciencia y Tecnología.

Daza-Caicedo, S., \& Lozano-Borda, M. (Eds.). (2014). Percepciones de las Ciencias y las Tecnologías en Colombia. Resultados de la III Encuesta Nacional de Percepción 
Pública de la Ciencia y la Tecnología. Bogota, Colombia: Observatorio Colombiano de Ciencia y Tecnología.

De Cheveigné, S. (2000). L’environnement dans les journaux télévisés. Médiateurs et visions du monde. Paris: CNRS Éditions.

de la Mata, D., \& Valencia-Amaya, M. G. (2014). The health impacts of severe climate shocks in Colombia. IDB Working Paper Series(498), 74.

Departamento Administrativo Nacional de Estadística (DANE). (2007). Colombia Una Nación Multicultural; Su diversidad étnica. Bogota.

Departamento Nacional de Planeación, \& Banco Interamericano de Desarrollo. (2014). Impactos Económicos del Cambio Climático en Colombia. Bogota: CEPAL - DNP BID.

Departamento Nacional de Planeación. (2015). Bases del Plan Nacional de Desarrollo 20142018. Departamento Nacional de Planeación.

Dixon, R. K., Brown, S., Houghton, R. A., Solomon, A. M., Trexler, M. C., \& Wisniewski, J. (1994). Carbon pools and flux of global forest ecosystems. Science, 263(5144), 185-190.

Domínguez, E., Hassidoff, A., León, J., Ivanova, Y., \& Rivera, H. (2009). Maximal, minimal and mean surface runoff in Colombia: How is it distributed? Journal of Environmental Hydrology, 17, 1-12.

Doyle, J. (2007). Picturing the Clima(c)tic: Greenpeace and the Representational Politics of Climate Change Communication. Science as Culture 16 (2), 129-150.

Duque, A., Stevenson, P. R., \& Feeley, K. J. (2015). Thermophilization of adult and juvenile tree communities in the northern tropical Andes. Proceedings of the National 
Academy of Sciences of the United States of America, 112(34), 10744-10749. doi:10.1073/pnas.1506570112

Falla, S., Hermelin, D., \& Aguirre, C. (2016). Conectar comunidades para construir sentidos sociales en torno al conocimiento. Trilogía. 8(15), 57-68.

García Acosta, V. (Coord.). (2008). Historia y desastres en América Latina. Vol. III. México: La Red, CIESAS.

García Romero, H. (2014). Deforestación en Colombia: retos y perspectivas. Fedesarrollo. Bogota: Fedesarrollo. Retrieved from http://hdl.handle.net/11445/337

Gentry, A. (1992). Tropical forest biodiversity: distributional patterns and their conservational significance. Oikos, 63, 19-28.

Government of Colombia. (2015, 09 07). Intended Nationally Determined Contribution. Document presented before UNFCCC. Bonn.

Hackett, E., Amsterdamska, O., Lynch, M., \& Wajcman, J. (Eds.). (2008). The Handbook of Science and Technology Studies (3a. ed.). Cambridge y Londres, Inglaterra: MIT Press.

Hellebrandt, D., \& Hellebrandt, L. (2010). Representations in the Brazilian media of the impacts of climate change in the coastal zone. [Representações na mídia Brasileira dos impactos das mudanças climáticas na zona costeira]. Pan-American Journal of Aquatic Sciences. 5(2), 126-137.

Hermelin, D. (2007). Los desastres naturales y los medios en Colombia: ¿información para la prevención?. Gestión y Ambiente. 10(2), 101-108.

Hermelin, D. (2011). Un contexto para la comunicación pública de la ciencia y la tecnología en Colombia: de las herencias eurocéntricas a los modelos para la acción. Coherencia. 14, 231-260. 
Hermelin, D. (2013). Desastres, medios masivos y comunicación pública de la ciencia: entre la vulnerabilidad y la cohesión social en Colombia y América Latina. Ensaio. Pesquisa em Educaçao em Ciencias. 15(3), 15-34.

Instituto de Hidrología, Meteorología y Estudios Ambientales (IDEAM). (2001). Primera Comunicación Nacional ante la Convención Marco de las Naciones Unidassobre el Cambio Climático. Instituto de Hidrología, Meteorología y Estudios Ambientales. Bogota. 307 p.

Instituto de Hidrología, Meteorología y Estudios Ambientales (IDEAM). (2010a). Segunda Comunicación Nacional ante la Convención Marco de las Naciones Unidas sobre Cambio Climático. Instituto de Hidrología, Meteorología y Estudios Ambientales. Bogota. 447 p.

Instituto de Hidrología, Meteorología y Estudios Ambientales (IDEAM). (2010b). Estrategia nacional de educación, formación y sensibilización de públicos sobre cambio climático. Bogota. 70 p.

Instituto de Hidrología, Meteorología y Estudios Ambientales (IDEAM). (2016). Cienciometria del cambio climatico en Colombia. 3ra Communicacion Nacional de Cambio Climatico. Instituto de Hidrología, Meteorología y Estudios Ambientales. Centro de Documentación e Información Científico Técnica. Republica de Colombia, Bogota 68 pp.

Instituto de Hidrología, Meteorología y Estudios Ambientales, PNUD, MADS, DNP, \& CANCILLERIA. (2015). Inventario nacional de gases de efecto invernadero (GEI) de Colombia. Bogota: IDEAM, PNUD, MADS, DNP, CANCILLERIA, FMAM. Instituto de Investigación de Recursos Biológicos Alexander von Humboldt . (2012). Informe sobre el estado de los recursos naturales renovables y del ambiente; Componente de 
biodiversidad, 2010-2011. Bogota: Instituto de Investigación de Recursos Biológicos Alexander von Humboldt.

Janif, S. Z., P. D. Nunn, P. Geraghty, W. Aalbersberg, F. R. Thomas, \& M. Camailakeba. (2016). Value of traditional oral narratives in building climate-change resilience: insights from rural communities in Fiji. Ecology and Society 21(2):7.

Jarvis, A., Touval, J. L., Schmitz, M. C., Sotomayor, L., \& Hyman, G. G. (2010). Assessment of threats to ecosystems in South America. Journal for Nature Conservation, 18, 180188. doi:10.1016/j.jnc.2009.08.003Krippendorff, K. (2004). Content Analysis. Thousand Oaks, California: Sage.

Landaburu, J. (2004). Las lenguas indígenas de Colombia: presentación y estado del arte. Amerindia(29-30), 3-22. Retrieved 08 17, 2016, from https://www.vjf.cnrs.fr/sedyl/amerindia/articles/pdf/A_29-30_00.pdf

Lima, N. (2013). Cambio climático: el drama de la información. Revista Nexus, (12), 258267.

López, J. (2008) La construction sociale du risque à Medellín (Colombie). Gouvernance locale et représentations. (PhD disertation). École de Hautes Études en Sciences Sociales de París. Advisor: Alain Musset.

Lorenzoni, I., Nicholson-Cole, S., \& Whitmarsh, L. (2007) Barriers perceived to engaging with climate change among the UK public and their policy implications. Global Environmental Change 17(3-4), 445-459.

Lozano-Borda, M., \& Maldonado, O. J. (Eds.). (2010). Estrategia Nacional de Apropiación Social de la Ciencia, la Tecnología y la Innovación. Bogota, Colombia: Colciencias. 
Maldonado, O. J., \& De Greiff, A. (2011). "Apropiación fuerte" del conocimiento: Una propuesta para construir políticas inclusivas de ciencia, tecnología e innovación en América Latina. In P. Kreimer, \& A. Arellano (Eds.), Estudio social de la ciencia y la tecnología desde América Latina. Bogotá, Colombia: Siglo del Hombre Editores.

Massarani, L., Hermelin, D., Montes de oca, A., Vara, A., Cevallos, M., Ramalho, M., Castelfranchi, J., \& de Castro Moerira, I. (2015). Monitoramento, capacitação e aprimoramentoem jornalismo científico em países do Mercosul. (65-92) Brasilia, Brasil: Ministério da Ciência, Tecnologia e Inovação.

Massarani, L., \& Ramalho, M. (Coord.). (2012). Monitoramento e capacitação em jornalismo científico: a experiência de uma rede ibero-americana. Rio de Janeiro, Brasil: Museu da Vida, Casa de Oswaldo Cruz, Fiocruz.

Mercado, M. T. (2012). Media representations of climate change in the argentinean press. Journalism Studies. 13(2), 193-209.

Ministerio de Ambiente y Desarrollo Sostenible \& Programa de las Naciones Unidas para el Desarrollo. (2014). Quinto Informe Nacional de Biodiversidad de Colombia ante el Convenio de Diversidad Biológica. Bogota.

Miralles, A. M. (2009). Periodismo público en la gestión del riesgo. Lima, Perú: PREDECAN, Comunidad Andina de Naciones.

Moirand, S. (1997). Formes discursives de la diffusion des savoirs dans les médias. Hermès, (21), 33- 44 .

Moser, S. C. (2010). Communicating climate change: history, challenges, process and future directions. Wiley Interdisciplinary Reviews: Climate Change, 1, 31-53. 
Mosser, S. C., \& Dilling, L. (2012) Communicating Climate Change: Closing the ScienceAction Gap. In: The Oxford Handbook of Climate Change and Society. DOI:10.1093/oxfordhb/9780199566600.003.0011

Murcia, C., Kattan, G. H., \& Andrade-Pérez, G. I. (2013). Americas: Conserving Biodiversity: The Case of Colombia. In N. S. Sodhi, L. Gibson, \& P. H. Raven, Conservation Biology: Voices from the Tropics (pp. 86-96). John Wiley \& Sons, Ltd. Myers, N., Mittermeier, R. A., Mittermeier, C. G., da Fonseca, G. A., \& Kent, J. (2000). Biodiversity hotspots for conservation priorities. Nature, 403, 853-858.

Nepstad, D., Bezerral, T., Tepper, D., McCann, K., Stickler, C., McGrath, D. G., Barrera, M. X., Lowery, S., Armijo, E., Higgins, M. L., Monschke, J., Gomez, R., Velez, S., Tejada, M., Tejada, M., Killeen, T, Schwalbe, K., \& Ruedas, A. (2013). Addressing Agricultural Drivers of Deforestation in Colombia: Increasing Land-Based Production While Reducing Deforestation, Forest Degradation, Greenhouse Gas Emissions and Rural Poverty. Report to the United Kingdom, Foreign and Commonwealth Office and Department of Energy Climate Change, Forests and Climate Change. Earth Innovation Institute, 102 p.

Nerlich, B., Koteyko, N., \& Brown, B. (2009). Theory and language of climate change communication. Wiley Interdisciplinary Reviews: Climate Change. 1 (1) 97 -110

Nisbet, M. C. (2009). Communicating climate change: Why frames matter for public engagement. Environment. 51(2), 12-25.

Obregón, R., Arroyave, J., Barrios, M. (2009). Cubrimiento Periodístico de la Gestión del Riesgo en la Subregión Andina, Discursos Periodísticos y Perspectivas desde la Comunicación para el Cambio Social.Centro Regional de Información sobre Desastres (CRID). Lima, 73 pp. 
Obregón, R., Arroyave, J., Barrios, M. (2010). Periodismo y comunicación para la gestión de riesgo en la subregión andina: discursos periodísticos y perspectivas para un enfoque prospectivo y preventivo". Folios. 23, 105-135.

Ochoa, A. (2016). Personnal communication. Professor at Universidad Nacional de Colombia (Medellin). e-mail: aochoaj@unal.edu.co.

Ockwell, D., Whitmarsh, L., \& O'Neill, S. (2009). Reorienting Climate Change Communication for Effective Mitigation. Science Communication, 30(3), 305-327.

O'neill, S., \& Nicholson-Cole, S. (2009). Fear Won't Do It. Science communication 3(30), $355-379$

Ottaviani, M., Squintani, F. (2006). Naive audience and communication bias. International Journal of Game Theory 35 (1), 129 - 150.

Painter, J. (2011) Poles Apart, The international reporting of climate skepticism. University of Oxford, Reuters Institute for the Study of Journalism. 144 p. (Available in http://reutersinstitute.politics.ox.ac.uk/publication/poles-apart. Accessed: 12-222016).

Pérez-Bustos, T., Franco Avellaneda, M., Lozano-Borda, M., Falla Morales, S., \& Papagayo, D. (2012). Iniciativas de apropiación social de la ciencia y la tecnologia em Colombia: tendencias y retos para una comprensión más amplia de estas. História, Ciências, Saúde-Manguinhos. 19 (1), 115-137.

Pérez-Bustos, T., \& Lozano-Borda, M. (Eds.). (2011). Ciencia, tecnología y democracia. Reflexiones en torno a la apropiación social del conocimiento. Medellín, Colombia: Colciencias \& Universidad EAFIT.

Poveda, G., Graham, N. E., Epstein, P. R., Rojas, W., Quiñones, M. L., Velez, I. D., \& Martens, W. J. (2000). Climate and ENSO variability associated with vector-borne 
diseases in Colombia. In: El Niño and the southern oscillation, Multiscale variability and global and regional impacts. Edited by Henry Diaz and Vera Markgraf. Cambridge University Press. 512 pp. 183-204.

Rabatel, A., Francou, B., Soruco, A., Gomez, J., Cáceres, B., Ceballos, J. L., . . . Wagnon, P. (2013). Current state of glaciers in the tropical Andes: A multi-century perspective on glacier evolution and climate change. Cryosphere, 7(1), 81-102. doi:10.5194/tc-7$81-2013$

Rey, G. (2008) La otra cara de la libertad. La responsabilidad social empresarial en medios de comunicación en América Latina. Bogotá, Colombia. FNPI, Fundación Carolina, Pontificia Universidad Javeriana, Avina.

Rey, G., Bonilla, J. I., \& Gómez, P. (2005). La Televisión del conflicto. La representación del conflicto armado colombiano en los noticieros de televisión. Bogotá, Colombia: Proyecto Antonio Nariño.

Ruiz García, F. A. (2006). La construcción de la territorialidad para los grupos étnicos en Colombia. Ib Revista de Información Básica, 1(2). Retrieved 08 18, 2016, from http://sitios.dane.gov.co/revista_ib/html_r2/articulo7_r2.htm

Ruiz-Peña, G. (2013). Acercando conocimientos para transformar realidades "caso estudio municipio de Cáqueza". (MSc thesis). Facultad de Ciencias Humanas. Universidad Nacional de Colombia-Sede Bogotá. Advisor: Yuri Jack Gómez.

Schäfer, M., Schlichting, I. (2014). Media Representations of Climate Change: A MetaAnalysis of the Research Field. Environmental Communication, 37 -49.

Scolari, C. (2009). Alrededor de la(s) convergencia(s). Conversaciones teóricas, divergencias conceptuales y transformaciones en el ecosistema de medios. Signo y Pensamiento, $28(54), 44-55$. 
Secretariat of the Convention on Biological Diversity. (2001). Global Biodiversity Outlook. Secretariat of the Convention on Biological Diversity. 283 pp.

Sirolli, E. (2012). Want to help someone? Shut up and listen (Ted Talk) https://www.ted.com/talks/ernesto_sirolli_want_to_help_someone_shut_up_and_lis ten/transcript

Takahashi, B. (2011). Framing and sources: A study of mass media coverage of climate change in Peru during the V ALCUE. Public Understanding of Science. 20(4), 543557.

Tamayo, C., \& Bonilla, J. (2014). El deber de la memoria. La agenda investigativa sobre la cobertura informativa del conflicto armado en Colombia, 2002-2012. Palabra Clave. 17(1), 13-45.

Ulloa, A. (Ed.). (2011). Perspectivas culturales del clima. Bogotá, Colombia: Ilsa y Universidad Nacional De Colombia.

Ulloa, A., \& Prieto-Rozo, A. I. (Eds.). (2013). Culturas, conocimientos, políticas y ciudadanías en torno al cambio climático. Bogotá: Universidad Nacional de Colombia y Colciencias.

Unidad Nacional para la Gestión del Riesgo de Desastres. (2014). Plan Nacional de Contingencia ante el fenómeno del Niño 2014-2015. Bogotá: Unidad Nacional para la Gestión del Riesgo de Desastres.

United Nations Development Programme/Global Environment Facililty (UNDP/GEF). (1999). Enabling the Republic of Colombia to prepare its initial National Communication in response to commitments to the UNFCCC. New York: United Nations Development Programme / Global Environment Facility 
Valencia, M. C. (2015). Guía periodística agenda verde: Una mirada a la problemática del medio ambiente y el cambio climático en las regiones de Colombia. Editors: Guerrero, O. C. et al. Bogotá, Colombia: Consejo de Redacción y Konrad Adenauer Stiftung.

Vella, J. (2002). Twelve principles for effective learning adult. In: Learning to listen, Learning to teach (revised edition) Jossey - Bass, San Francisco

West, R. C. (1957). The pacific lowlands of Colombia: a negroid area of the American tropics. Baton Rouge: Louisiana State University Press.

Zamith, R, Pinto, J., Vilar, M. (2013). Constructing Climate Change in the Americas: An Analysis of News Coverage in U.S. and South American Newspapers. Science Communication. 35 (3), 334-357.

\section{Noted}

\footnotetext{
$\mathrm{i}$ "Black communities" is the term most used in the Colombian Constitution of 1991 and subsequent regulations. It is not considered racist. The terms "Afro-Colombian" and "Afro-Descendant" are less used, and were only introduced around the 1990s. There is still debate amongst community members on which term they consider more appropriate, and there are strong defenders of both lines. Out of respect for those communities with whom we work, who feel proud to be Black, and do not identify with the term Afro-Colombian, we will use the term Black throughout this article.

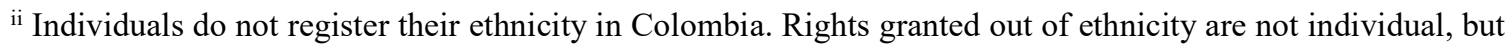
collective.

${ }^{\text {iii }}$ Humid and dry above-treeline steppes, often growing on highly-organic peat substrates

iv See Nisbeth (2009) for further references on approaches to framing.

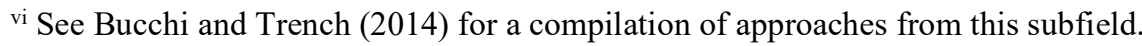


${ }^{\text {ix }}$ Rather than one single policy, the country has developed a portfolio of documents, which include: 1) Institutional Strategy for the Articulation of Policies and Actions Regarding Climate Change in Colombia (2011), 2) National Plan for Climate Change Adaptation (2012), 3) Financial Strategy to Reduce the Country’s Fiscal Vulnerability before Natural Disasters (2012), and 4) the National Strategy for the Education, Training and Sensitization of Audiences on Climate Change (2010). There are also non-adopted white papers with guidelines for policies, including the Guidelines for a Climate Change Policy, developed in 2002, and the Framework for the Colombian Strategy on Climate Financing, developed in 2016.

x http://colombiatic.mintic.gov.co/estadisticas/stats.php?\&pres=content\&jer=1\&cod=\&id=25\#TTC. Accessed January 19,2017

${ }^{\mathrm{xi}}$ http://www.internetlivestats.com/internet-users/colombia/. Accessed January 19, 2017

xii http://www.internetworldstats.com/south.htm\#co. Accessed January 19, 2017

xiii https://www.dnp.gov.co/programas/ambiente/CambioClimatico/Paginas/Cambio-Climatico.aspx. Accessed January 19, 2017

${ }^{\mathrm{xiv}}$ http://www.cancilleria.gov.co/cambio-climatico-0. Accessed January 19, 2017

${ }^{x v}$ https://www.minagricultura.gov.co/Cambio_Climatico/Paginas/Cambio-Climatico.aspx

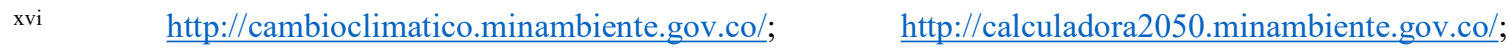

http://www.minambiente.gov.co/index.php/ambientes-y-desarrollos-sostenibles/cambio-climatico._Accessed January 19, 2017

xvii The microsite can be accessed through the addresses http://www.cambioclimatico.gov.co/ and http://www.ideam.gov.co/web/cambio-climatico/. Accessed January 19, 2017

xviii www.siac.gov.co. Accessed January 19, 2017

${ }^{\text {xix }}$ According to submission note FCCC/SBI/2012/MISC.15 to the UNFCCC, reporting on donations involved on the preparation of National Communications, projects other than the cited generated information that was used in the communication. Those resources are not accounted here.

${ }^{x x}$ Semi-discursive approximations for similar subjects from De Cheveigné (2000) and CEDISCOR (1992) can also be considered.

xxi Data reported by the agency temporarily created to address this long-term disaster. See: http://www.colombiahumanitaria.gov.co/FNC/Documents/2014/estudio caso.pdf. (Consulted 25-08-2016). 